\title{
Comparative Study of Different Materials with Al-Sic for Engine Valve Guide by Using FEM
}

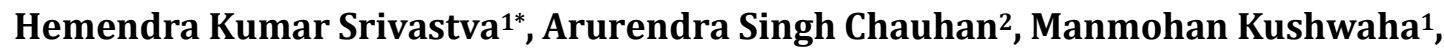 \\ Amaan Raza1, Prashantkr Bhardwaj', Vaibhav Raj ${ }^{1}$ \\ ${ }^{1}$ Department of Mechanical Engineering, Naraina Group of Institutions, Kanpur, India \\ ${ }^{2}$ Department of Mechanical Engineering, Maharana Pratap Engineering College, Kanpur, India \\ Email: "hemendra28@rediffmail.com
}

Received 17 March 2016; accepted 14 May 2016; published 17 May 2016

Copyright (C) 2016 by authors and Scientific Research Publishing Inc.

This work is licensed under the Creative Commons Attribution International License (CC BY). http://creativecommons.org/licenses/by/4.0/

(c) (1) Open Access

\begin{abstract}
In this work, an effort has been designed to raise the reliability of engine using Al-Sic composites with other alternatively materials for the engine valve guides. Aluminum matrix composites have found the most suitable inside automotive, aerospace and aircraft industries and contain the greatest promise for future year's growth. The finite element analysis of the Al-Sic composite with Titanium alloy (Ti-834), Copper Nickel Silicon alloys (CuNi3Si), and aluminum bronze alloy as an alternative material for engine valve guide was done using Ansys 13.0 software. The stress analysis of engine valve guide under the different pressure and temperature is considered, the pressure is taken as from $10 \mathrm{MPa}$ to $100 \mathrm{MPa}$ with different temperatures varying from $600^{\circ} \mathrm{C}$ to $650^{\circ} \mathrm{C}$. The temperature, principal stress and principal strain distribution on the entire surface area of the engine valve guide were obtained. The stresses were observed to be well below the permitted stress for all the materials but the Al-Sic composites found the most suitable one. Valve guide is modeled in pro-engineer software and analysis is carried out in Ansys 13.0. The deformations and stresses induced due to structural and thermal loading is illustrated and discussed.
\end{abstract}

\section{Keywords}

Valve Guide, Composite Materials, FEM, Deformation, Von Mises Stress

\section{Introduction}

In reaction to increasing worldwide competition and developing concern for environment, the auto manufactur-

${ }^{*}$ Corresponding author.

How to cite this paper: Srivastva, H.K., Chauhan, A.S., Kushwaha, M., Raza, A., Bhardwaj, P. and Raj, V. (2016) Comparative Study of Different Materials with Al-Sic for Engine Valve Guide by Using FEM. World Journal of Engineering and Technology, 4, 238-251. http://dx.doi.org/10.4236/wjet.2016.42023 
ers have already been encouraged to meet up the conflicting demands of increased power and performance, lower fuel consumption, lower pollution emission and reduced vibration and noise. To be able to fulfill these newer and emerging needs, the automobile industry has acknowledged the necessity for materials substitution. Metal matrix composites are providing outstanding properties in a true number of automotive components such as for example piston, cylinder liner, engine valves, brake discs, brake drums, clutch discs, linking rods etc. Several function has been documented on the substitution of presently utilized materials by the aluminum matrix composites for various automotive parts viz. piston, cylinder liner, engine valves, valve seat inserts etc. $\mathrm{Al}$-Sic composite engine valve guides have already been fabricated through powder metallurgy and casting processes. The radial crushing strength, hardness, and wear resistance of the Al-SiC cast and composite iron engine valve guides were measured and compared. Al-SiC composites with 5 to $30 \mathrm{wt} . \%$ of $\mathrm{SiC}$ were discovered to have increased Rockwell hardness and radial crushing strength compared to the cast iron engine valve guides. Al-SiC composite engine valve guides with 20 and $30 \mathrm{wt} \%$ of $\mathrm{SiC}$ were discovered to possess higher wear level of resistance compared to the cast iron engine valve guides. Existing work incorporates the finite element strategy to include the prospects of Al-SiC composites just as one alternative material for the engine valve guides. The finite element Analysis of the engine valve guides was done making use of Ansys 13.0 software program. Temperature, displacement and pressure boundary conditions were used and the temperature, stress and stress distribution on the entire surface area of the engine valve guides was obtained. Aluminum alloys have discovered greater adoption while potential matrix materials in comparison to some other alloys.

In 2000, Katsunao Chikahata, Koichiro Hayashi (Publication number US6012703 A) [1] presented valve guide and process for manufacturing, they say that valve guide which is manufactured by a sintered alloy and used for an engine, and more particularly, to a valve guide which has high wear resistance and can prevent appearance of scuffing on a surface of a valve stem associated with the valve guide.

In 2009, Suhael Ahmed [2] presented the Development and Characterization of Al7075 Based Hybrid Composites. Aluminum based Metal matrix composites have been emerged as an important class of materials for structural, wear, thermal, transportation and electrical applications.

Srinivasa R. Bakshi, Di Wang, Timothy Price, Arvind Agarwal in 2009, [3] presented Microstructure and Wear properties of Aluminum/Aluminum-Silicon Composite coatings prepared by cold spraying.

Manoj Singla, D. Deepak Dwivedi, Lakhvir Singh, Vikas Chawla in 2009, [4] shows developed a conventional low cost method of producing MMCs and to obtain homogenous dispersion of ceramic material.

In 2011, Dunia Abdul Saheb [5] Presented Aluminum silicon carbide and aluminum graphite Particulate composites.

Raman preet Singh, Er. Rahul Singla in 2012 [6] presented Tribological Characterization of Aluminium-Silicon Carbide Composite Prepared by Mechanical Alloying Aluminium Metal Composites is combinations of materials in such a way that the resulting materials have certain design properties on improved quality.

In 2014 P. S. Chaitanya [7] compared Aluminium alloy 6061 with Aluminium Alloy A204 for a cylinder fin body which is modeled and transient thermal analysis is performed by using Pro/Engineer and ANSYS. These fins are used for air cooling systems for two wheelers. The various parameters (i.e., geometry and thickness of the fin) are considered in the study, By reducing the thickness and also by changing the shape of the fin to circular shape from the traditional geometry i.e. rectangular, the weight of the fin body reduces thereby increasing the heat transfer rate and efficiency of the fin. And concluded that through the use of circular fin with material Aluminium Alloy 6061 is better since heat transfer rate of the fin is more and also by using circular fins the weight of the fin body reduces compared to existing rectangular engine cylinder fin.

Silva F.S [8] in the year 2006 has analyzed fatigue damaged piston. Damaged starts at the crown, ring grooves, pin holes and skirt are examined. An analysis of both thermal fatigue and structural or mechanical fatigue damages is analyzed in his work. A linear static stress analysis applying "cosmos" is used to determine the stress distribution during the combustion. Stresses at the piston crown and pin holes as well as stresses at the groove and skirt as a function of land clearances are also discussed by him.

Ekrem Buyukkaya [9] back in 2007 has investigated a standard (uncoated) diesel engine piston made of aluminum silicon alloy and steel. He carried out thermal analyses on piston coated with $\mathrm{Mgo}-\mathrm{ZrO}_{2}$ material by using a commercial code ANSYS. Finally the result of four diversed pistons is compared with one another. The results of coatings on the thermal behaviors of the piston are investigated and it is concluded that the maximum 
surface temperature of the coated pistons with the material which has low thermal conductivity is improved approximately $48 \%$ for AlSi alloys and 35\% for the steel.

Yanxia Wang [10] in the year 2010 stated a solid model including piston and piston pin of a new designed of piston by Pro-E software and then the same model is analyzed by finite element method using ANSYS tool. The thermo-mechanical coupling stress distribution and the deformation were firstly calculated taking into the consideration of the nonlinear material properties of piston and piston pin, the Newto-Raphson equilibrium iterative method is used. Finally the results indicate that the maximum stress concentration is at the upper end of the piston pin boss inner hole and is mainly caused by the peak pressure of the fuel gas.

Ali Belhocine [11] in 2014 analyzed the thermo mechanical behavior of the dry contact between the brake disc and pads during the braking phase by using software ANSYS11 and shown that the ventilation system plays an important role in cooling the discs and provides a good high-temperature resistance. The analysis results showed that temperature field and stress field in the process of braking phase were fully coupled. The temperature, the Von Mises stress and the total deformations of the disc and contact pressures of the pads increases as the thermal stresses are apart from the mechanical stress which causes the crack propagation and fracture of the bowl and wear of the disc and pads.

Kang and Cho [12] analyzed the geometry of vents in motorcycle disc brakes which affects the surface of the disc and the thermal characteristics of disc brakes. Thermal deformation analysis and thermal stress analysis due to heat transfer were carried out through the finite element analysis for ventilated disc and solid disc. For 3-dimensional modeling and finite element analysis of the discs, the commercial code ANSYS Workbench was used.

Yasar Deger [13] Noticed that the efficiency of the interdisciplinary multi physics analyses and the quality of their results are highly dependent on the probability to access the knowledge and expertise of company specialists in finite element applications, materials sciences and fluid dynamic. An example of such a close cooperation at Sulzer Innotec was the numerical analysis of the thermo mechanical stresses in the exhaust manifold of a diesel engine with active water cooling system. CFD analyses for three stationary operational conditions with variable cooling flow were performed because of this exhaust manifold looking to determine specific temperature and pressure distributions. The fluid flow and the heat transfer through the exhaust manifold were computed by CFD analyses correspondingly including the conjugate heat transfer.

Relating to Zhu Maoqina [14] Calculation on the exhaust manifold is completed predicated on coupling of CFD and FEA software the distribution of temperature and thermal stress of exhaust manifold of stainless is demonstrated.

In 2013, Sweta Jain [15] presented the Sequential Coupled Thermal-Structural Analysis to investigate the associated thermal stresses and deformations under simulated operational conditions close to the real situation on different materials. Analysis carried out by reference environmental testing conditions; in different ambient temperatures on different materials i.e. cast iron, structural steel. And observed that the critical area of thermal stress concentration and deformation on both the materials are similar. Stress concentrations can be interpreted as significant indices for extreme temperature levels and temperature gradients. The Results shows that both studied material, Cast Iron (FG 260) and Structural Steel are appropriate for the investigated Exhaust Manifold of off-road vehicle diesel engine.

In 2011, Hemendra Kr Srivastava [16] analyzed the die cavity for the cap using a finite element package ANSYS 10. The cap cavity plate is analyzed for different pressure load cases. and for every pressure load deflection and von mises stresses are calculated and concluded that the structure is safe under the given loading conditions.

In the year 1997 Cuddy M.R [17] stated that for every $10 \%$ weight reduction of the vehicle, an extensive improvement in fuel consumption of $6 \%$ to $8 \%$ is anticipated. Better engine design needs optimized engine component. Advanced tools are required to analyze engine components. Engine piston is one of the key component among the entire automotive component and other industry field components. Engine is the heart of automobile and piston is considered the most crucial part of an engine. Numerous advanced Aluminum piston analysis methods have been reported in the past years. In the year 2008, NajimA. Saad [18] did the numerical analysis to investigate the stresses due to thermal cycle with different aluminum alloy of piston. Finite element method was used to determine the thermal stress on the piston. ANSYS5.4 Finite element code is utilized to carry out the modeling process and determine the coupling stresses. Two models with three dimensions are created. The first 
model is used to evaluate the temperature distribution through the piston volume and the second is used to evaluate the thermal stress distribution due to heat gradient and different materials. The result shows the maximum range of temperature is $43^{\circ} \mathrm{C}$ and increases with decreasing of material thermal conductivity. Thermal stress is concentrated on the piston edges and depends on the material type.

P. Gudim et al. [19] in the year 2009 suggested a CAD model of a damaged internal combustion engine piston and by using the finite element analysis tool ANSYS to perform a linear static and a coupled thermal-structural analysis of the component. Further, a parametric analysis of the material properties in comparisons with operating condition is carried out to create a relational database for the piston to arrive at optimum design solution under different working conditions.

Y. Zeng [20] in the year 2010 build up a geometry model of a diesel engine piston using UG graphics software. The temperature areas of the piston for burning diesel and DME (Dimethyl Ether Fueled Diesel Engine) separately are computed using ANSYS 10.0. The result demonstrates that the variation of the thermal loads by substituting diesel fuel with DME fuel is within the thermal strength of material. The temperature of DME fueled diesel engine decreases along the piston axis from top to bottom. Temperature of the piston of DME fueled engine increase as comparing with burning diesel.

Piotr Szurgott [21] in the year 2011 has analyzed the behavior of the combustion engine piston manufactured from different kind of materials under thermal loading conditions. A thermo mechanical Finite element evaluation of the engine piston made of composite materials was done. The selected engine is installed in another of popular polish tanks. The proposed new materials are seen as a low hysteresis-the distinctions of the coefficient of thermal expansion for and cooling heating aren't significant. A geometrical model of the piston was developed based on the geometry of the actual object that was scanned utilizing a $3 \mathrm{~d}$ laser beam scanner. The next phase was to build up the solid geometrical model based on the dimensions from the laser scanning and the points cloud data. The pistons of the S12U engine are constructed of PA12 aluminum alloy. A new composite material with low hysteresis was considered also. Such materials allow reducing the difference of the coefficient of thermal expansion for cooling and heating and as a result it increases the dimensional stability of the piston.

\section{Problem Specification}

Issue of sustainbility, stability, durability and reliebility of prsent material for engine guide valve at high tempreture about $600^{\circ} \mathrm{C}$ to $1000^{\circ} \mathrm{C}$ under very high pressure about $10 \mathrm{mpa}-100 \mathrm{mpa}$.

At the moment the engine valve guides are made of iron-based materials, which result in a true amount of problems within an automotive engine

- During cold start condition the viscosity of oil is high and also sufficient lubricant is not available therefore high wear of the valve stem/valve guide takes place. In the adverse conditions the valve may jam in the guide.

- During running condition of the engine the temperature of the valve stem and valve guide increases to about $500^{\circ} \mathrm{C}$. Therefore at high temperature the clearance between valves stem and valve guide decreases due to thermal expansion, which results in high wear of the valve stem and the guide.

- The superimposed rocking motion in addition to the sliding of the engine valve causes high wear at the ends of the valve guide called "bell-mouthing", generally more pronounced in the rocker arm actuation mechanism.

These problems call for a high wear resistant material with low coefficient of thermal expansion and engine valve guides based on the $\mathrm{Al}-\mathrm{SiC}$ composites are expected to provide a better solution.

\subsection{Material and Properties}

Al SIC composites

Mechanical properties

\begin{tabular}{cccc}
\hline Material & Elastic Modulus (GPa) & Poisson ratio & Rockwell Hardness (HRC) \\
\hline $\mathrm{Al} \mathrm{10 \%}$ wt. of $\mathrm{SiC}$ & 77.4 & 0.33 & 46.5 \\
$\mathrm{Al}$ 20\% wt. of $\mathrm{SiC}$ & 86 & 0.32 & 51.5 \\
$\mathrm{Al} \mathrm{30 \%}$ wt. of $\mathrm{SiC}$ & 92 & 0.31 & 53 \\
\hline
\end{tabular}


Thermal properties

\begin{tabular}{ccc}
\hline Material & $\begin{array}{c}\text { Coefficient of thermal expansion } \\
\left(\times 10^{-7} /{ }^{\circ} \mathrm{k}\right)\end{array}$ & $\begin{array}{c}\text { Thermal Conductivity } \\
\mathrm{W} / \mathrm{m} . \mathrm{K}\end{array}$ \\
\hline $\mathrm{Al} 10 \%$ wt. of $\mathrm{SiC}$ & 2.0 & 173 \\
$\mathrm{Al} 20 \%$ wt. of $\mathrm{SiC}$ & 1.75 & 168 \\
$\mathrm{Al} 30 \%$ wt. of $\mathrm{SiC}$ & 1.55 & 164 \\
\hline
\end{tabular}

\subsection{Titanium Alloy (Ti-834)}

Properties

\begin{tabular}{cc}
\hline Modulus of elasticity X-Direction (Pa) & $1.2 \mathrm{e}+011$ \\
Thermal expansion coefficient X-Direction & $1.2 \mathrm{e}-006$ \\
Major Poisson's ratio Z-Plane & 0.31 \\
Minor Poisson's ratio Z-Plane & 0.31 \\
Density $\left(\mathrm{kg} / \mathrm{m}^{3}\right)$ & 4550 \\
Thermal conductivity X-Direction (w/m.k) & 25 \\
\hline
\end{tabular}

\subsection{Copper Nickel Silicon Alloy (CuNi3Si)}

Properties

\begin{tabular}{cc}
\hline Modulus of elasticity X-Direction (Pa) & $1.3 \mathrm{e}+011$ \\
Thermal expansion coefficient X-Direction & $1.6 \mathrm{e}-006$ \\
Major Poisson's ratio Z-Plane & 0.32 \\
Minor Poisson's ratio Z-Plane & 0.32 \\
Density $\left(\mathrm{kg} / \mathrm{m}^{3}\right)$ & 8870 \\
Thermal conductivity X-Direction (w/m.k) & 230 \\
\hline
\end{tabular}

\section{Temperature Distribution}

To understand the problem of wear and decreasing the clearance the clearance due to temperature change at various load condition, firstly have to analyze the temperature distribution in the valve and valve guide.

Typically we take example of exhaust valve temperature distribution in spark ignition engine of V-8 car with full throttle $(3500 \mathrm{r} / \mathrm{min})$. During expansion stoke the temperature of the burnt gases is about $600^{\circ} \mathrm{C}-800^{\circ} \mathrm{C}$. These hot burnt gases get impact with head of poppet valve and head of poppet valve conduct the heat through various portion of poppet valve.

- Small part about $30 \%$ of the heat is conducted through valve seat and remaining $70 \%$ heat conduct through valve stem.

- $25 \%$ heat conducted through valve stem is further conduct through valve guide.

Due to this impact of hot gases, the temperature at the center of head is maximum about $700^{\circ} \mathrm{C}$ and further distributed at various element, nodes and section as shown in figure below.

Temperature at the starting section of valve stem is $613^{\circ} \mathrm{C}$ and at the open end of valve guide is about $580^{\circ} \mathrm{C}$ and further temperature distribute in different nodes and elements as shown in the figure below and at other end of valve guide the temperature is about $390^{\circ} \mathrm{C}$.

\subsection{Problem Analysis}

At this temperature range, materials which are currently used for guide valve expands due to which the clearance between valve stem and valve guide get reduced which creates a lot of problems in the valve operating system such as: 
- Valve stems breakage

- Burnt Valve seat

- Valve Stem to Valve Guide Seizure

- Mechanical Damages

- Excessive Valve Stem \& Valve Guide Wear

- Valve Tip Breakage etc.

\subsection{Analysis of Engine Guide Valve}

Finite element method has become one of the most widely used techniques, for analyzing mechanical loading characteristics in modern engineering components. Traditional analysis techniques can only be satisfactorily applied to a range of conventional component shapes and specific loading conditions. Unfortunately, the majority of engineering loading situations are not simple and straight forward therefore the traditional techniques often need to be modified and compromised to suit situations for which they were not intend. The uncertainty thus created, commonly leads to the designer applying excessively high factor of safety to the mechanical loads and so to over design components by specifying either unnecessarily bulky cross section or high quality materials, inevitably the cost of the product is adversely affected.

Before using Valve guide in the I.C. Engine first of all we have to check its deformation, Vonmises stressesStrain value, Maximum \& Minimum principle stress-strain and its failure point at every load conditions. FEA is the best method of determining the deformation, Vonmises stresses-Strain value, Maximum \& Minimum principle stress-strain and its failure point at each and every load conditions. Main advantage of FEA is that it converts the problem into a number of elements and nodes and then solve problem and give the result at every element and node. It also State that at which node the material is going to fail at which load condition. Therefore this can make our material safe in all load condition. In this way, FEM is applied (using Ansys software ) on Valve guide for making a comparative study of Aluminium silicon carbide of different compositions with other materials (which are currently in use):

- Titanium alloy (Ti-834) (used in racing Cars).

- Copper Nickel Silicon Alloy (CuNi3Si) (used in locomotive).

At different load conditions such as:

Different temperatures varying from $550^{\circ} \mathrm{C}$ to $1000^{\circ} \mathrm{C}$.

Pressure varying from $10 \mathrm{MPa}$ to $100 \mathrm{MPa}$.

Modeling has been carried in pro-engineering software. The Engine guide valve is drawn in Pro-E (Figure 1). Sketch of the guide valve is done in the sketcher part of the Pro-Engineering. The section of the guide valve is revolved to $360^{\circ}$ about the central axis to obtain 3D model of guide valve. The inner wall and outer wall is inclined angle $92^{\circ}$.

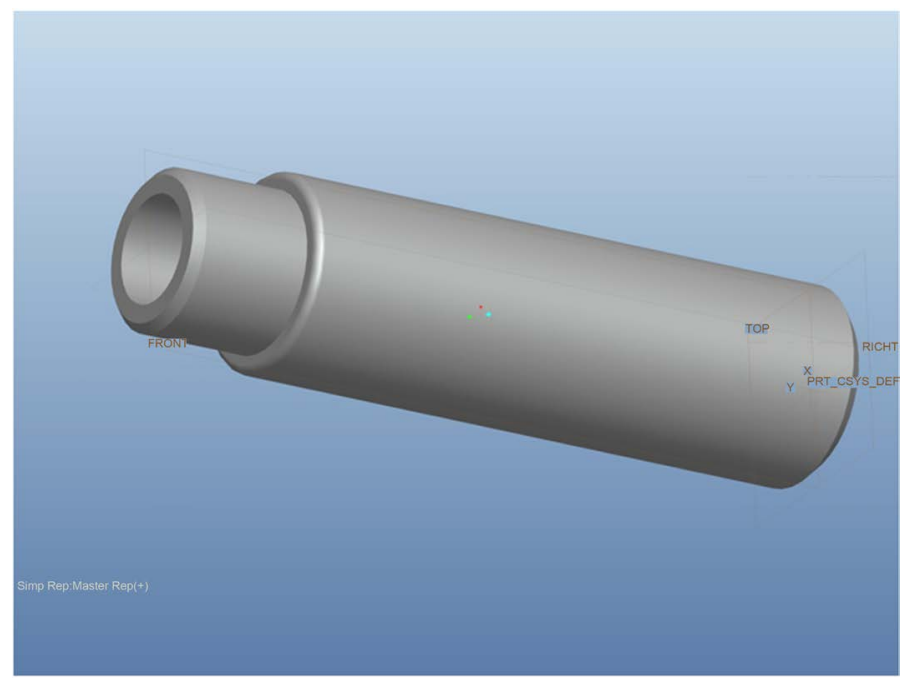

Figure 1. Geometric modeling. 


\subsection{Finite Element Model of Guide Valve}

Analysis of guide valve is carried over in following steps.

Guide valve model has been modeled in the pro-engineer as shown in Figure 2. For performing the analysis over the guide valve a finite element model is necessary. In order to get the good quality mesh and to maintain the tetrahedron elements, the cap cavity plate is meshed in hyper mesh 12.0 Hyper mesh 12.0 is the product from Altair Hyper Works is a commercially available software package. It mainly used for the finite element modeling of the components. Guide valve as shown in Figure 2 is retrieved in hyper mesh using solid 10 node 92 element type(From Ansys library) is used to mesh the Guide valve and a converged mesh is shown in Figure 3. A Solid 10 node 87 element type is used for thermal analysis.

\section{Result and Discussion}

Case I: When the pressure is $10 \mathrm{MPa}$ and $1 \mathrm{MPa}$ and temperature is $600^{\circ} \mathrm{C}$ and $400^{\circ} \mathrm{C}$.

From the resultant variation (Figure 4 and Figure 5) the maximum deformation is $0.0169 \mathrm{~mm}$ and 0.01436 $\mathrm{mm}$ is at inside of guide valve when the material is $\mathrm{Al} 10 \%$ Sic and $\mathrm{Al} 20 \%$ Sic and subjected pressure is 10 MPa at top and 1 MPa at bottom.

From the resultant variation (Figure 6 and Figure 7) the maximum deformation is $0.0778 \mathrm{~mm}$ and $0.124 \mathrm{~mm}$ is at inside of guide valve when the material is titanium alloy and CuNi3Si alloy and subjected pressure is 10 $\mathrm{MPa}$ at top and $1 \mathrm{MPa}$ at bottom. The variation of deformation as material is changed is shown in Table 1.

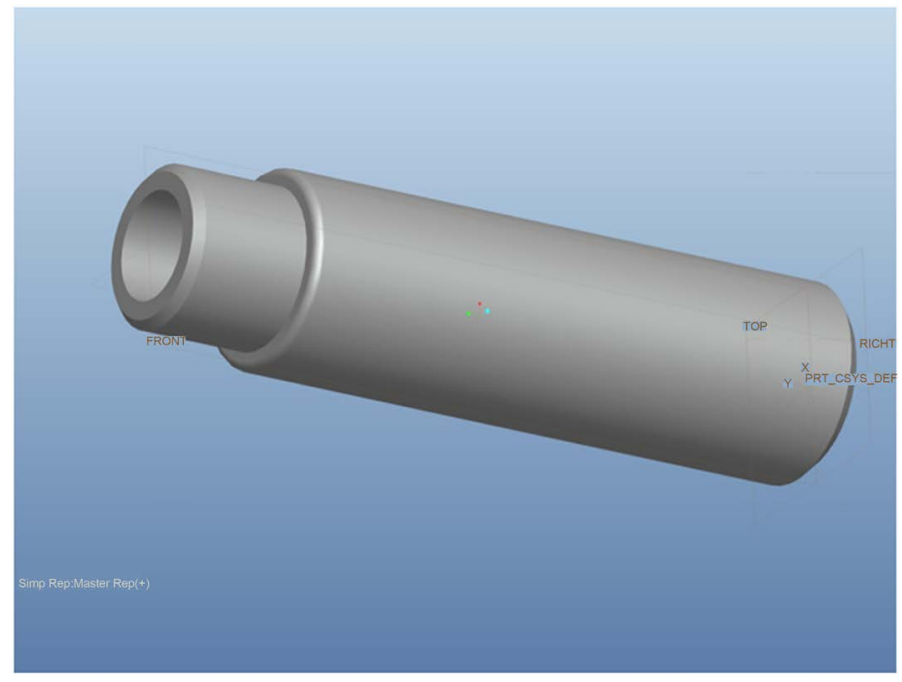

Figure 2. Guide valve.

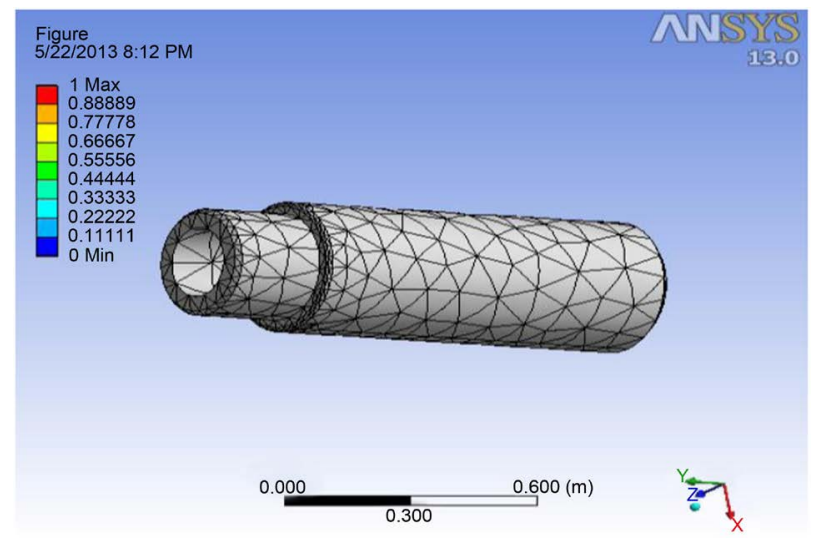

Figure 3. Meshed model of guide valve. 


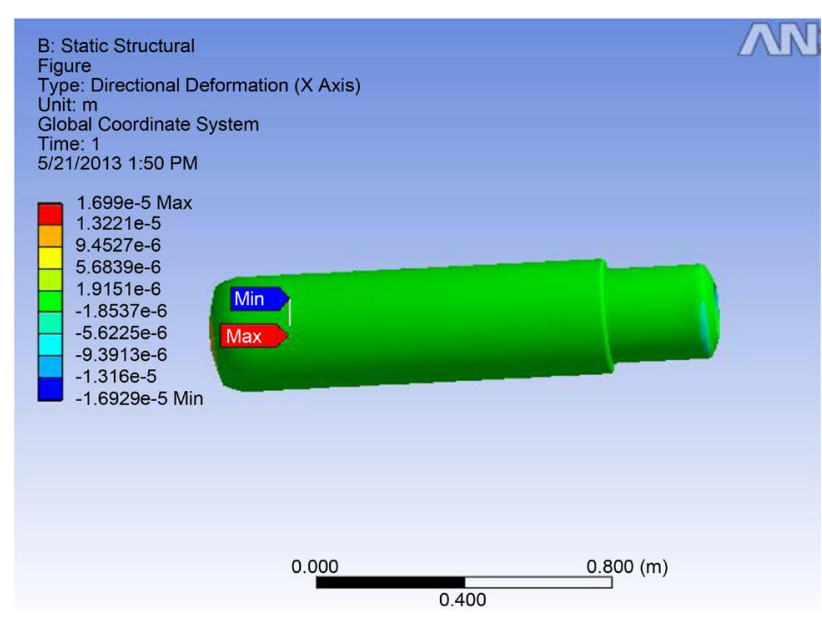

Figure 4. Deformation variation for $\mathrm{Al} 10 \%$ Sic material guide valve.

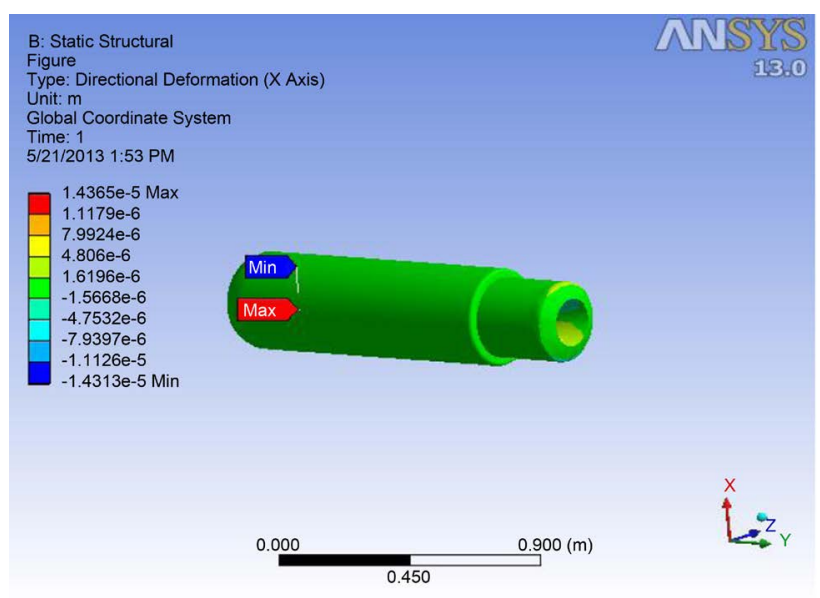

Figure 5. Deformation variation for $\mathrm{Al} 20 \%$ Sic material guide valve.

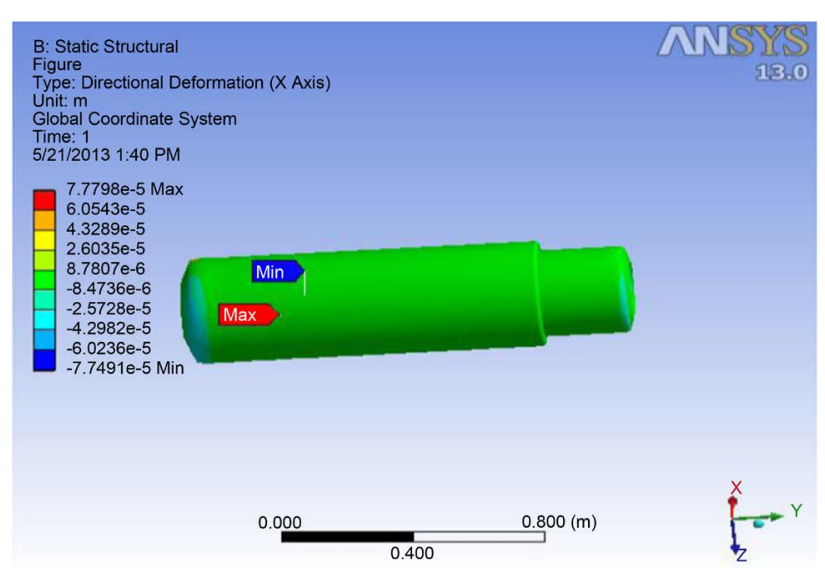

Figure 6. Deformation variation for titanium alloy guide valve.

From Table 1 and Figures 8-15 it is clear that the deflection is varying with change of material it is minimum

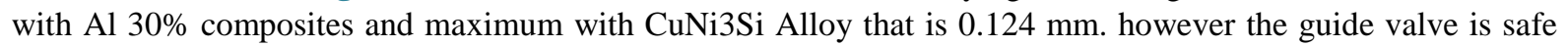
due to very less deformation. 
Table 1. Deformation with material.

\begin{tabular}{cccccc}
\hline Result/Material & $\mathrm{Al}$ 10\% composites & $\mathrm{Al} 20 \%$ composites & Al 30\% composites & Titanium Alloy (Ti 834) & CuNi3Si Alloy \\
\hline Deformation & $0.0169 \mathrm{~mm}$ & $0.01436 \mathrm{~mm}$ & $0.0123 \mathrm{~mm}$ & $0.0778 \mathrm{~mm}$ & $0.124 \mathrm{~mm}$ \\
\hline
\end{tabular}

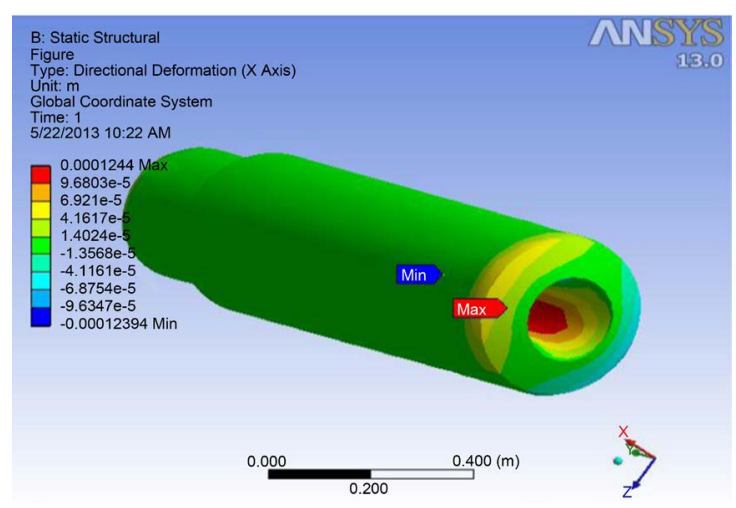

Figure 7. Deformation variation for CuNi3Si Alloy guide valve.

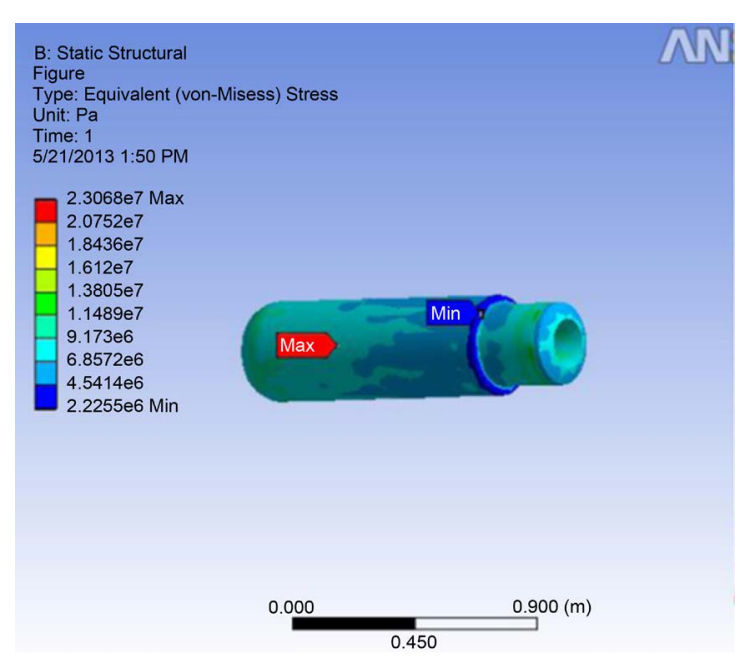

Figure 8. Von mises stress for $\mathrm{Al} 10 \%$ Sic material guide valve.

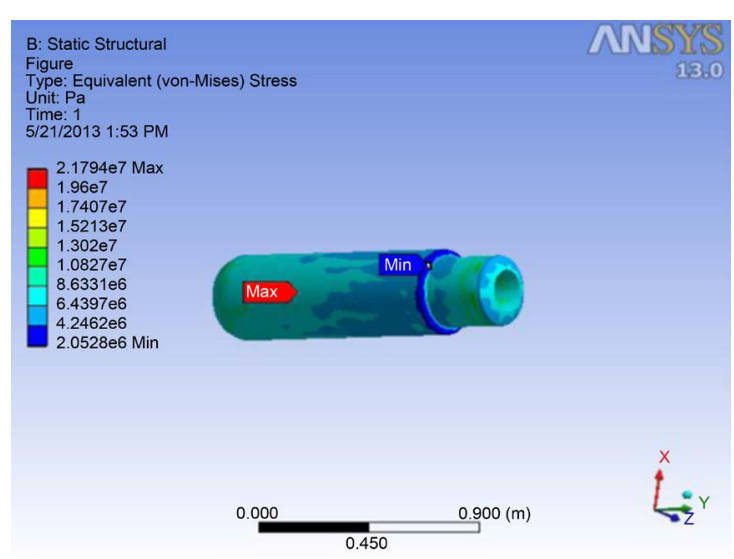

Figure 9. Von mises stress for $\mathrm{Al} 20 \%$ Sic material guide valve. 


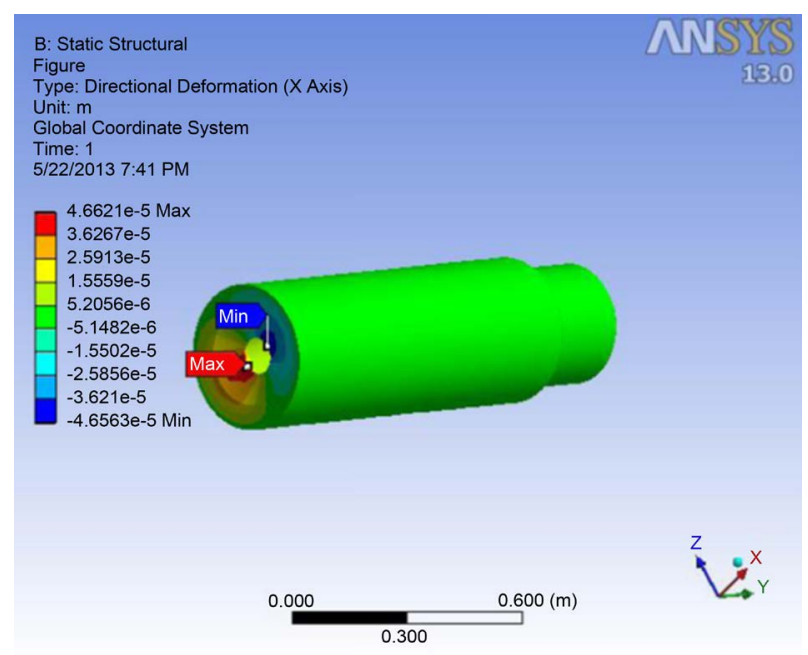

Figure 10. Deformation variation for $\mathrm{Al} 30 \%$ Sic material guide valve.

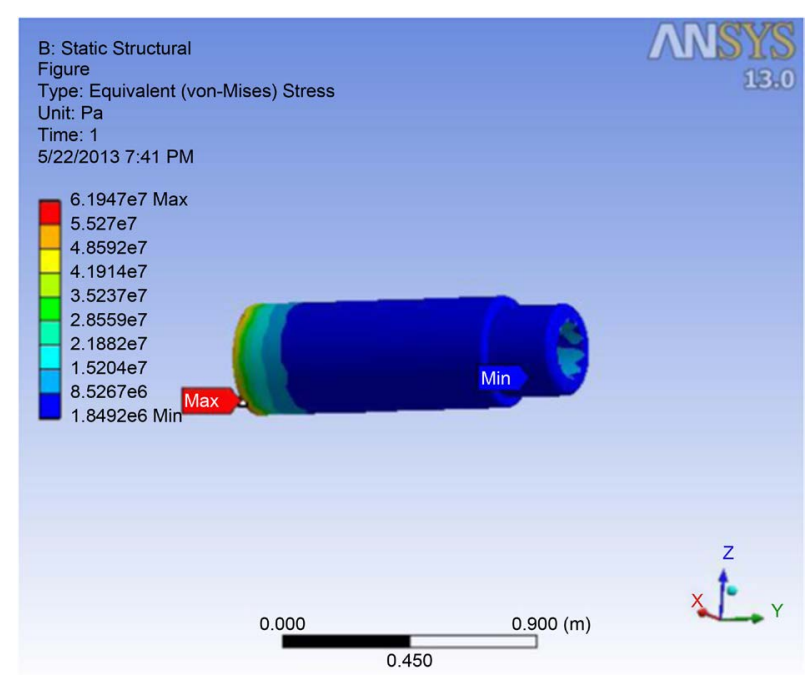

Figure 11. Von mises stress for $\mathrm{Al} 30 \%$ Sic material guide valve.

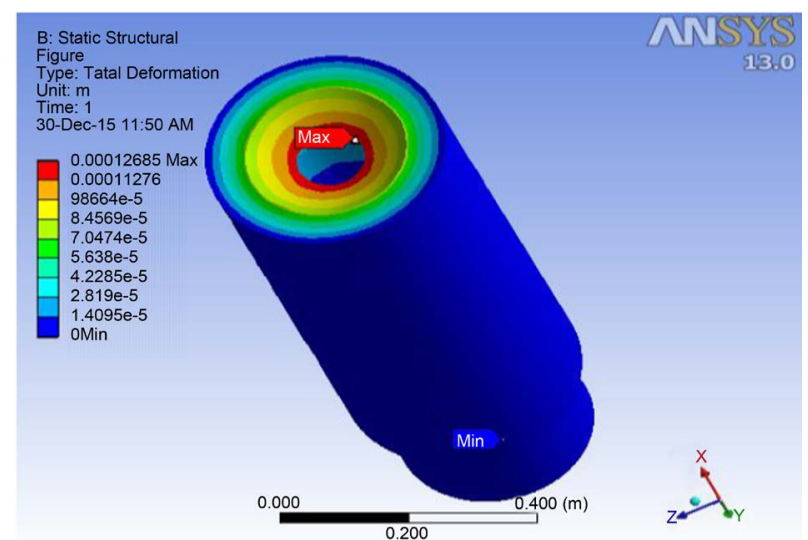

Figure 12. Deformation variation for $\mathrm{Al} 30 \%$ Sic material guide valve. 
Table 2 shows the resultant displacement and resultant stress of the guide valve under the different material conditions. under the constant load condition of $10 \mathrm{MPa}$, and $1 \mathrm{Mpa}$ the safe stress is $23.06 \mathrm{MPa}$, 21.79 $\mathrm{MPa}$, 20.09 MPa, 165.39 MPa, 286.31 MPa, when the guide valve is made up of $\mathrm{Al} 10 \%$ composites, $\mathrm{Al} 20 \%$ composites, Al 30\% composites, Titanium Alloy (Ti 834), CuNi3Si Alloy, respectively. Which is not exceeded the material yield stress respectively. It is concluded that when the von mises stress are less than the yield stress

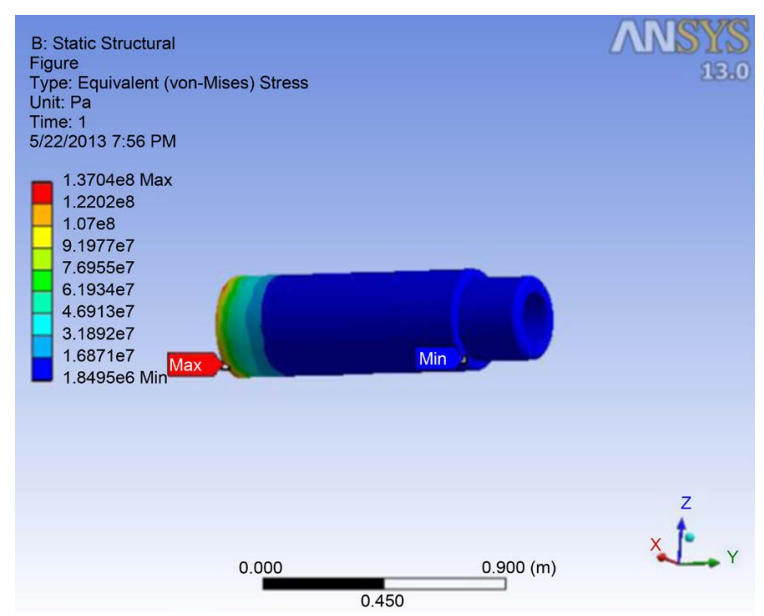

Figure 13. Von mises stress for Al $30 \%$ Sic material guide valve.

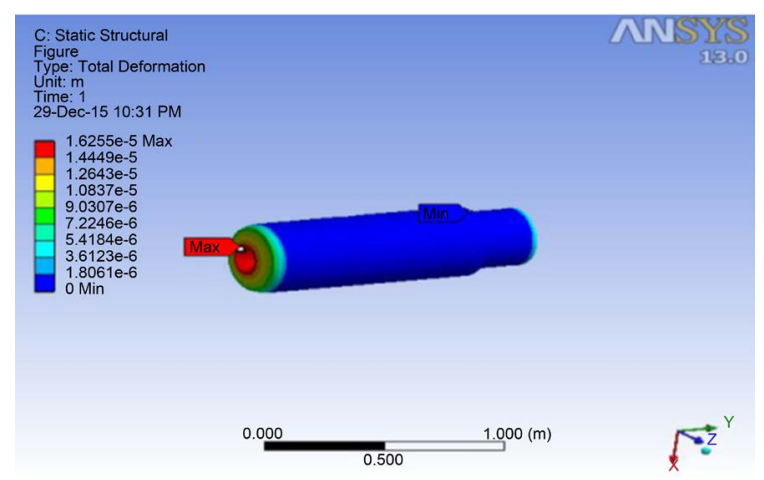

Figure 14. Deformation variation for $\mathrm{Al} 30 \%$ Sic material guide valve.

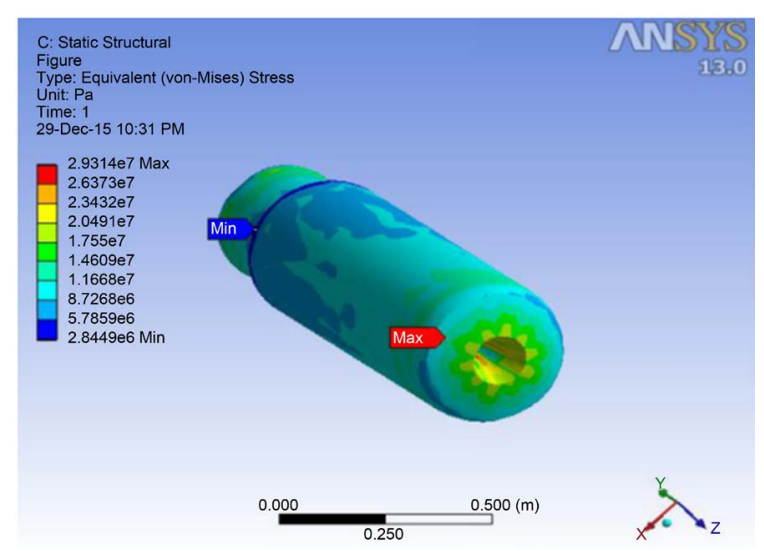

Figure 15. Von mises stress for $\mathrm{Al} \mathrm{30 \%} \mathrm{Sic} \mathrm{material} \mathrm{guide}$ valve. 
there the guide valve will be safe. And when the von mises stress are more than the yield stress than the structure will be failed.

Case II: When the pressure is $50 \mathrm{MPa}$ and $5 \mathrm{MPa}$ and temperature is $600^{\circ} \mathrm{C}$ and $400^{\circ} \mathrm{C}$.

The pressure load of $50 \mathrm{Mpa}$ at bottom and $5 \mathrm{MPa}$, at top and temperature of $600^{\circ} \mathrm{C}$, at bottom and $400^{\circ} \mathrm{C}$ at top is applied and deformations and stresses are computed on guide valve.

Case III: When the pressure is $100 \mathrm{MPa}$ and $10 \mathrm{MPa}$ and temperature is $600^{\circ} \mathrm{C}$ and $400^{\circ} \mathrm{C}$.

The pressure load of $100 \mathrm{Mpa}$ at bottom and $10 \mathrm{MPa}$, at top and temperature of $600^{\circ} \mathrm{C}$, at bottom and $400^{\circ} \mathrm{C}$ at top is applied and deformations and stresses are computed on guide valve.

Case IV: When the pressure is $10 \mathrm{MPa}$ and $1 \mathrm{MPa}$ and temperature is $650^{\circ} \mathrm{C}$ and $450^{\circ} \mathrm{C}$.

The pressure load of $10 \mathrm{Mpa}$ at bottom and $1 \mathrm{MPa}$, at top and temperature of $650^{\circ} \mathrm{C}$, at bottom and $450^{\circ} \mathrm{C}$ at top is applied and deformations and stresses are computed on guide valve.

\section{Conclusion}

Static and thermal analysis is carried over guide valve. The guide valve is analyzed for different pressure load cases (as shown in Tables 1-5). At a pressure of $10 \mathrm{MPa}$ and $1 \mathrm{MPa}$ and temperature $600^{\circ} \mathrm{C}$ and $400^{\circ} \mathrm{C}$, the maximum deformation is $0.124 \mathrm{~mm}$ and maximum stress is found to be $286.31 \mathrm{MPa}$ (CuNi3Si Alloy). Stresses developed for this pressure for all the materials are less than their respective yield strength. In the same way when the guide valve is analyzed for the different set of pressure and temperature parameters (i.e. pressure 50 $\mathrm{MPa}$ and $5 \mathrm{MPa}$ and temperature is $600^{\circ} \mathrm{C}$ and $400^{\circ} \mathrm{C}$ ), (pressure $100 \mathrm{MPa}$ and $10 \mathrm{MPa}$ and temperature is $600^{\circ} \mathrm{C}$ and $400^{\circ} \mathrm{C}$ ), (pressure is $10 \mathrm{MPa}$ and $1 \mathrm{MPa}$ and temperature is $650^{\circ} \mathrm{C}$ and $450^{\circ} \mathrm{C}$ ) the max deformation is found to be $0.2268 \mathrm{~mm}, 0.1816 \mathrm{~mm}, 0.1244 \mathrm{~mm}$ respectively and max stress is found $338.30 \mathrm{MPa}, 340.94 \mathrm{Mpa}$, 367.18 Mpa in CuNi3Si Alloy. However, it has been observed that at high temperature the stresses produced in $\mathrm{Al}$-SiC composites are very less as compared to other materials at different parameters (pressure \& temperature

Table 2. Deformation and Von mises stress according to respective materials.

\begin{tabular}{|c|c|c|c|c|c|c|c|c|}
\hline \multicolumn{2}{|c|}{ Load (MPa) } & \multicolumn{2}{|c|}{ Temp ${ }^{\circ} \mathrm{C}$} & \multirow[b]{2}{*}{ Material } & \multirow[b]{2}{*}{$\begin{array}{l}\text { Max. deforma- } \\
\text { tion, mm }\end{array}$} & \multirow[b]{2}{*}{$\begin{array}{l}\text { Von-mises, } \\
\text { MPa }\end{array}$} & \multirow[b]{2}{*}{ Safety/Failure } & \multirow[b]{2}{*}{$\begin{array}{c}\text { Material yield } \\
\text { stress MPa }\end{array}$} \\
\hline $\begin{array}{c}\text { Max } \\
\text { (bottom) }\end{array}$ & $\begin{array}{l}\text { Min } \\
\text { (Top) }\end{array}$ & $\begin{array}{c}\text { Max } \\
\text { (bottom) }\end{array}$ & $\begin{array}{c}\text { Min } \\
\text { (Top) }\end{array}$ & & & & & \\
\hline 10 & 01 & 600 & 400 & $\begin{array}{c}\mathrm{Al} 10 \% \\
\text { composites }\end{array}$ & $0.0169 \mathrm{~mm}$ & $23.06 \mathrm{MPa}$ & Safe & $257 \mathrm{MPa}$ \\
\hline 10 & 01 & 600 & 400 & $\begin{array}{c}\mathrm{Al} 20 \% \\
\text { composites }\end{array}$ & $0.01436 \mathrm{~mm}$ & $21.79 \mathrm{MPa}$ & Safe & $263 \mathrm{MPa}$ \\
\hline 10 & 01 & 600 & 400 & $\begin{array}{c}\mathrm{Al} \mathrm{30 \%} \\
\text { composites }\end{array}$ & $0.0123 \mathrm{~mm}$ & $20.09 \mathrm{MPa}$ & Safe & $269 \mathrm{MPa}$ \\
\hline 10 & 01 & 600 & 400 & $\begin{array}{l}\text { Titanium Alloy } \\
\text { (Ti 834) }\end{array}$ & $0.0778 \mathrm{~mm}$ & $165.39 \mathrm{MPa}$ & Safe & $910 \mathrm{MPa}$ \\
\hline 10 & 01 & 600 & 400 & CuNi3Si Alloy & $0.124 \mathrm{~mm}$ & $286.31 \mathrm{MPa}$ & Safe & $550 \mathrm{MPa}$ \\
\hline
\end{tabular}

Table 3. Deformation and Von mises stress according to respective materials.

\begin{tabular}{|c|c|c|c|c|c|c|c|c|}
\hline \multicolumn{2}{|c|}{ Load (MPa) } & \multicolumn{2}{|c|}{ Temp ${ }^{\circ} \mathrm{C}$} & \multirow[b]{2}{*}{ Material } & \multirow[b]{2}{*}{$\begin{array}{l}\text { Max. deforma- } \\
\text { tion, mm }\end{array}$} & \multirow[b]{2}{*}{$\begin{array}{c}\text { Von-mises, } \\
\mathrm{MPa}\end{array}$} & \multirow[b]{2}{*}{ Safety/Failure } & \multirow[b]{2}{*}{$\begin{array}{c}\text { Material yielc } \\
\text { stress MPa }\end{array}$} \\
\hline $\begin{array}{c}\text { Max } \\
\text { (bottom) }\end{array}$ & $\begin{array}{l}\text { Min } \\
\text { (Top) }\end{array}$ & $\begin{array}{c}\text { Max } \\
\text { (bottom) }\end{array}$ & $\begin{array}{l}\text { Min } \\
\text { (Top) }\end{array}$ & & & & & \\
\hline 50 & 5 & 600 & 400 & $\begin{array}{c}\text { Al } 10 \% \\
\text { composites }\end{array}$ & $0.0564 \mathrm{~mm}$ & $60 \mathrm{MPa}$ & Safe & $257 \mathrm{MPa}$ \\
\hline 50 & 5 & 600 & 400 & $\begin{array}{c}\text { Al } 20 \% \\
\text { composites }\end{array}$ & $0.05034 \mathrm{~mm}$ & $59.79 \mathrm{MPa}$ & Safe & $263 \mathrm{MPa}$ \\
\hline 50 & 5 & 600 & 400 & $\begin{array}{c}\text { Al 30\% } \\
\text { composites }\end{array}$ & $0.04662 \mathrm{~mm}$ & $61.94 \mathrm{MPa}$ & Safe & $269 \mathrm{MPa}$ \\
\hline 50 & 5 & 600 & 400 & $\begin{array}{c}\text { Titanium Alloy } \\
\text { (Ti 834) }\end{array}$ & $0.12907 \mathrm{~mm}$ & $200.33 \mathrm{MPa}$ & Safe & $910 \mathrm{MPa}$ \\
\hline 50 & 5 & 600 & 400 & CuNi3Si Alloy & $0.2268 \mathrm{~mm}$ & $338.30 \mathrm{MPa}$ & Safe & $550 \mathrm{MPa}$ \\
\hline
\end{tabular}


Table 4. Deformation and Von mises stress according to respective materials.

\begin{tabular}{|c|c|c|c|c|c|c|c|c|}
\hline \multicolumn{2}{|c|}{ Load (MPa) } & \multicolumn{2}{|c|}{ Temp ${ }^{\circ} \mathrm{C}$} & \multirow[b]{2}{*}{ Material } & \multirow[b]{2}{*}{$\begin{array}{l}\text { Max. deformation, } \\
\text { mm }\end{array}$} & \multirow[b]{2}{*}{$\begin{array}{l}\text { Von-mises, } \\
\text { MPa }\end{array}$} & \multirow[b]{2}{*}{ Safety/Failure } & \multirow[b]{2}{*}{$\begin{array}{l}\text { Material yield } \\
\text { stress MPa }\end{array}$} \\
\hline $\begin{array}{c}\text { Max } \\
\text { (bottom) }\end{array}$ & $\begin{array}{l}\text { Min } \\
\text { (Top) }\end{array}$ & $\begin{array}{c}\text { Max } \\
\text { (bottom) }\end{array}$ & $\begin{array}{l}\text { Min } \\
\text { (Top) }\end{array}$ & & & & & \\
\hline 100 & 10 & 600 & 400 & $\begin{array}{l}\text { Al 10\% } \\
\text { composites }\end{array}$ & $0.192 \mathrm{~mm}$ & $\begin{array}{l}129.65 \\
\mathrm{MPa}\end{array}$ & Safe & $257 \mathrm{MPa}$ \\
\hline 100 & 10 & 600 & 400 & $\begin{array}{l}\mathrm{Al} 20 \% \\
\text { composites }\end{array}$ & $0.16189 \mathrm{~mm}$ & $\begin{array}{c}131.94 \\
\mathrm{MPa}\end{array}$ & Safe & $263 \mathrm{MPa}$ \\
\hline 100 & 10 & 600 & 400 & $\begin{array}{c}\mathrm{Al} 30 \% \\
\text { composites }\end{array}$ & $0.1268 \mathrm{~mm}$ & $\begin{array}{l}132.93 \\
\mathrm{MPa}\end{array}$ & Safe & $269 \mathrm{MPa}$ \\
\hline 100 & 10 & 600 & 400 & $\begin{array}{l}\text { Titanium Alloy } \\
\text { (Ti 834) }\end{array}$ & $0.00986 \mathrm{~mm}$ & $\begin{array}{l}202.87 \\
\mathrm{MPa}\end{array}$ & Safe & $910 \mathrm{MPa}$ \\
\hline 100 & 10 & 600 & 400 & CuNi3Si Alloy & $0.1816 \mathrm{~mm}$ & $\begin{array}{c}340.94 \\
\mathrm{MPa}\end{array}$ & Safe & $550 \mathrm{MPa}$ \\
\hline
\end{tabular}

Table 5. Deformation and Von mises stress according to respective materials.

\begin{tabular}{|c|c|c|c|c|c|c|c|c|}
\hline \multicolumn{2}{|c|}{ Load (MPa) } & \multicolumn{2}{|c|}{ Temp ${ }^{\circ} \mathrm{C}$} & \multirow[b]{2}{*}{ Material } & \multirow[b]{2}{*}{$\begin{array}{l}\text { Max. deformation, } \\
\text { mm }\end{array}$} & \multirow[b]{2}{*}{$\begin{array}{c}\text { Von-mises, } \\
\mathrm{MPa}\end{array}$} & \multirow[b]{2}{*}{ Safety/Failure } & \multirow[b]{2}{*}{$\begin{array}{l}\text { Material yield } \\
\text { stress MPa }\end{array}$} \\
\hline $\begin{array}{c}\text { Max } \\
\text { (bottom) }\end{array}$ & $\begin{array}{l}\text { Min } \\
\text { (Top) }\end{array}$ & $\begin{array}{c}\text { Max } \\
\text { (bottom) }\end{array}$ & $\begin{array}{l}\text { Min } \\
\text { (Top) }\end{array}$ & & & & & \\
\hline 100 & 10 & 600 & 400 & $\begin{array}{c}\text { Al 10\% } \\
\text { composites }\end{array}$ & $0.020315 \mathrm{~mm}$ & $\begin{array}{c}25.968 \\
\mathrm{MPa}\end{array}$ & Safe & $257 \mathrm{MPa}$ \\
\hline 100 & 10 & 600 & 400 & $\begin{array}{c}\text { Al 20\% } \\
\text { composites }\end{array}$ & $0.01734 \mathrm{~mm}$ & $\begin{array}{c}26.183 \\
\mathrm{MPa}\end{array}$ & Safe & $263 \mathrm{MPa}$ \\
\hline 100 & 10 & 600 & 400 & $\begin{array}{c}\text { Al 30\% } \\
\text { composites }\end{array}$ & $0.01625 \mathrm{~mm}$ & $\begin{array}{c}29.314 \\
\mathrm{MPa}\end{array}$ & Safe & $269 \mathrm{MPa}$ \\
\hline 100 & 10 & 600 & 400 & $\begin{array}{l}\text { Titanium Alloy } \\
\text { (Ti 834) }\end{array}$ & $0.0778 \mathrm{~mm}$ & $\begin{array}{c}216.61 \\
\mathrm{MPa}\end{array}$ & Safe & $910 \mathrm{MPa}$ \\
\hline 100 & 10 & 600 & 400 & CuNi3Si Alloy & $0.1244 \mathrm{~mm}$ & $\begin{array}{c}367.18 \\
\mathrm{MPa}\end{array}$ & Safe & $550 \mathrm{MPa}$ \\
\hline
\end{tabular}

both) from the results obtained finally, it is figured that $\mathrm{Al} / \mathrm{sic}_{\mathrm{p}}$ is suitable materials for high temperature applications i.e. Turbo charged engines, racing cars, diesel loco engines air craft engines where cost is not a major factor.

\section{References}

[1] Chikahata, K. and Hayashi, K. (2000) US Patent Publication Number US6012703 A.

[2] Ahmed, S. (2013) Development and Characterization of Al7075 Based Hybrid Composites. Indian Journal of Research, 2.

[3] Bakshi, S.R., Wang, D., Price, T. and Agarwal, A. (2009) Composite Material-Aluminium Silicon Alloy: A Review. Indian Journal of Research.

[4] Singla, M., Dwivedi, D.D., Singh, L. and Chawla, V. (2009) Development of Aluminium Based Silicon Carbide Particulate Metal Composits.

[5] Saheb, D.A. (2011) Aluminum Silicon Carbide and Aluminum Graphite Particulate Composites. ARPN Journal of Engineering and Applied Sciences, 6.

[6] Singh, R. and Singla, Er.R. (2012) Tribological Characterization of Aluminium-Silicon Carbide Composite Prepared by Mechanical Alloying. International Journal of Applied Engineering Research, 7.

[7] Chaitanya, P.S. (2014) Thermal Analysis of Engine Cylinder Fin by Varying Its Geometry and Material. IOSR Journal of Mechanical and Civil Engineering (IOSR-JMCE), 11, 37-44.

[8] Silva, F.S. (2006) Fatigue on Engine Pistons-A Compendium of Case Studies. Engineering Failure Analysis, 13, 480492.

[9] Buyukkaya, E. and Cerit, M. (2007) Thermal Analysis of a Ceramic Coating Diesel Engine Piston Using 3-D Finite Element Method. Surface and Coatings Technology, 202, 398-402. 
[10] Wang, Y.X., Liu, Y.Q. and Shi, H.Y. (2010) Simulation and Analysis of Thermo-Mechanical Coupling Load and Mechanical Dynamic Load for a Piston. IEEE, 106-110.

[11] Belhocine, A. (2014) Structural and Thermal Analysis of Automotive Disc Brake Rotor. Archive of Mechanical Engineering.

[12] Kang, S.S. and Cho, S.K. (2012) Thermal Deformation and Stress Analysis of Disk Brakes by Finite Element Method. Journal of Mechanical Science and Technology, 26, 2133-2137.

[13] Deger, Y., Simperl, B. and Jimenez, L.P. (2004) CFD-FE-Analysis for the Exhaust Manifold of a Diesel Engine. Sulzer Innotec, Sulzer Markets and Technology Ltd., Winterthur.

[14] Zhu, M.Q., Lv, J.C. and Zhong, X.B. (2012) Development for Stainless Steel Exhaust Manifold and CAE Analysis. Advance Material Research, Vol. 462, Trans Tech Publications, Switzerland.

[15] Jain, S. and Agrawal, A.B. Coupled Thermal-Structural Finite Element Analysis for Exhaust Manifold of an Off-Road Vehicle Diesel Engine. International Journal of Soft Computing and Engineering (IJSCE), 3.

[16] Srivastava, H.K. (2011) Design and Analysis of Injection Molding of Mineral Water Bottle Cap. International Journal of Applied Engineering Research, 6, 1525-1534.

[17] Cuddy, M.R. and Wipke, K.B. (1997) Analysis of Fuel Economy Benefit of Drive Train. Hybridization. http://www.nrel.gov/vechicle fuels/vsa/pdfs/22309.pdf

[18] Saad, N.A., Abed Ali, H.R. and Abudalla, H.S. (2008) Numerical Analysis of the Thermal-Stresses of a Petrol Engine Piston with Different Materials. The Iraqi Journal for Mechanical and Material Engineering, 8, 249-256.

[19] Gudimetal, P. and Gopinath, C.V. (2009) Finite Element Analysis of Reverse Engineered Internal Combustion Engine Piston. AIJSTPME, 2, 85-92.

[20] Wu, Y., Zeng, D.J. and Feng, Z.Y. (2010) Finite Element Analysis for the Thermal Load of Piston in a Dimethyl Ether Fueled Diesel Engine. IEEE, Wuhan, 26-28 June 2010, 2895-2898. http://dx.doi.org/10.1109/mace.2010.5536084

[21] Szurgott, P. and Niezgoda, T. (2011) Thermo-Mechanical FE Analysis of the Piston Made of Composite Material with Low Hyteresis. Journal of Kones Power Train and Transport. 